\title{
Deterministic seismic hazard macrozonation of India
}

\author{
Sreevalsa KolathayaR*, T G Sitharam and K S Vipin \\ Department of Civil Engineering, Indian Institute of Science, Bangalore 560 012, India. \\ *Corresponding author.e-mail: sreevals@civil.iisc.ernet.in
}

Earthquakes are known to have occurred in Indian subcontinent from ancient times. This paper presents the results of seismic hazard analysis of India $\left(6^{\circ}-38^{\circ} \mathrm{N}\right.$ and $\left.68^{\circ}-98^{\circ} \mathrm{E}\right)$ based on the deterministic approach using latest seismicity data (up to 2010). The hazard analysis was done using two different source models (linear sources and point sources) and 12 well recognized attenuation relations considering varied tectonic provinces in the region. The earthquake data obtained from different sources were homogenized and declustered and a total of 27,146 earthquakes of moment magnitude 4 and above were listed in the study area. The sesismotectonic map of the study area was prepared by considering the faults, lineaments and the shear zones which are associated with earthquakes of magnitude 4 and above. A new program was developed in MATLAB for smoothing of the point sources. For assessing the seismic hazard, the study area was divided into small grids of size $0.1^{\circ} \times 0.1^{\circ}$ (approximately $10 \times$ $10 \mathrm{~km}$ ), and the hazard parameters were calculated at the center of each of these grid cells by considering all the seismic sources within a radius of 300 to $400 \mathrm{~km}$. Rock level peak horizontal acceleration (PHA) and spectral accelerations for periods 0.1 and $1 \mathrm{~s}$ have been calculated for all the grid points with a deterministic approach using a code written in MATLAB. Epistemic uncertainty in hazard definition has been tackled within a logic-tree framework considering two types of sources and three attenuation models for each grid point. The hazard evaluation without logic tree approach also has been done for comparison of the results. The contour maps showing the spatial variation of hazard values are presented in the paper.

\section{Introduction}

A large number of devastating earthquakes have occurred in India and it is estimated that more than $50 \%$ of the country's land area is vulnerable to earthquakes. The northern region of India, which is along the plate boundary of Indian plate with Eurasian plate, is seismically very active. The northeastern movement of Indian plate has caused deformation in the Himalayan region, Tibet and the northeastern India. Along the Himalayan belt, the Indian and Eurasian plates converge at the rate of $50 \mathrm{~mm}$ /year (Bilham 2004; Sridevi 2004; Kumar et al. 2007). The northeast Indian (NEI) region is known as one of the most seismically active regions in the world. However, the peninsular India, which is far away from the plate boundary, is a stable continental region, which is considered to be of moderate seismic activity. Even though the activity is considered to be moderate in the peninsular India, world's deadliest earthquake occurred in this region (Bhuj earthquake 2001). The improper building construction techniques adopted in the rural areas and the high population density are the major causes for the heavy damage due to earthquakes in India.

For a developing country like India, the steps towards seismic hazard evaluation are very essential to estimate an optimum and reliable value of possible earthquake ground motion during a specific time period. These predicted values will be an input to assess the seismic vulnerability of an area

Keywords. India; seismic hazard; deterministic approach; ground motion; peak horizontal acceleration. 
based on which new construction and the restoration works of existing structures can be carried out. The latest version of seismic zoning map of India given in the earthquake resistant design code of India [BIS-1893 (Part 1) 2002] assigns four levels of seismicity for the entire country in terms of different zone factors. The main drawback of the seismic zonation code of India (BIS-1893 2002) is that, it is based on the past seismic activity and not based on a comprehensive scientific seismic hazard analysis. Several seismic hazard studies, which were taken up in recent years, have shown that the hazard values given by BIS-1893 (2002) need to be revised (Raghu Kanth and Iyengar 2006; Mahajan et al. 2009; Vipin et al. 2009, etc.). These things necessitate a comprehensive study for evaluating the seismic hazard of India and development of a seismic zonation map of India based on the peak horizontal acceleration (PHA) values.

The first attempt to evaluate the seismic hazard of Indian subcontinent based on deterministic techniques was done by Parvez et al. (2003). This study considered 40 seismogenic sources in India and was classified based on seismicity, tectonics and geodynamics (Parvez et al. 2003). The PHA values were reported for four locations in south India and the maximum PHA value reported was $0.08 \mathrm{~g}$. The seismic hazard of Bangalore was evaluated by Sitharam and Anbazhagan (2007) based on deterministic approach using the attenuation relation suggested by Iyengar and Raghu Kanth (2004). Joshi et al. (2007) evaluated the seismic hazard of northeast India deterministically based on the modelling of finite rupture plane along the identified lineaments in the region using semi-empirical techniques. The seismic hazard of Chennai city was evaluated by Boominathan et al. (2008) based on deterministic approach. This work has also evaluated the site effects and reported the values of the characteristic site period and spectral acceleration ratio for Chennai city.

In view of the major advancement made in understanding the seismicity and seismotectonics of this region, an updated deterministic seismic hazard map of India covering $6^{\circ}-38^{\circ} \mathrm{N}$ and $68^{\circ}-98^{\circ} \mathrm{E}$ has been prepared and presented in this paper. The outcome consists of seismic hazard contour maps of India for the horizontal component of ground motion for different structural periods (PHA, spectral acceleration at 0.1 and $1.0 \mathrm{~s}$, on bed rock conditions).

\section{Seismicity of the Indian region}

Tectonic framework of Indian subcontinent covering an area of about 3.2 million $\mathrm{km}^{2}$ is spatiotemporarily varied and complex. The rapid drifting of Indian plate towards Himalayas in the northeastern direction with a high velocity along with its low plate thickness (Kumar et al. 2007) might be the cause for an increase in the seismicity of the Indian region. Indian plate is moving northward at about $5 \mathrm{~cm}$ per year and it collides with the Eurasian Plate. Upon the Eurasian Plate lie the Tibet plateau and central Asia. When continents converge, large amounts of shortening and thickening take place, like at the Himalayas and the Tibet. Due to this massive collision, the Himalayas were formed and large number of earthquakes are generated due to this process. This plate boundary extends from Himalayan regions to the Arakan Yoma and is a major cause of earthquakes in this region. In a similar process, involving the Indian Plate and the Burmese microplate, results in earthquakes in the Andaman and Nicobar Islands. In addition to this, there are earthquakes occurring within the Indian shield region, in the Indian peninsula and in adjoining parts of the Arabian Sea or the Bay of Bengal.

Majority of earthquakes occur along narrow zones that follow the edges of tectonic plates. These events are known as Inter-Plate or Plate Boundary earthquakes. These earthquakes are the direct result of the interaction between two or more tectonic plates. Sometimes earthquakes occur far away from plate boundaries. These arise due to localized systems of forces in the crust, sometimes associated with ancient geological structures such as in the Rann of Kachchh. Seismic activity of this nature contributes $1 \%$ of the annual seismic energy release globally. All earthquakes in peninsular India fall within this category.

Geographical statistics of India show that almost $54 \%$ of the land is vulnerable to earthquakes. The plate boundary areas along the Himalayan and the Indo-Burmese arcs, along with the intervening area of northeast India, are characterized by very high level of seismicity (Gupta 2006). The analysis of the seismic activity in India can be broadly characterized by three general seismotectonic considerations (figure 1); tectonically active shallow crustal region, subduction zones and stable continental region. The subduction zone earthquakes can be further divided as regions with intraslab and interface earthquakes.

\subsection{Active tectonics shallow crustal region}

The seismicity of the Himalayan arc tectonic belt is associated with the underthrusting of the Indian plate beneath the Eurasian plate (Krishnan 1953; Molnar and Tapponnier 1979). The tectonically active interplate regions include the Himalayas and southern Tibetan Plateau, northwest frontier province of Indian plate (Kayal 2008; Nath and Thingbaijam 2010). The movement of Indian plate 


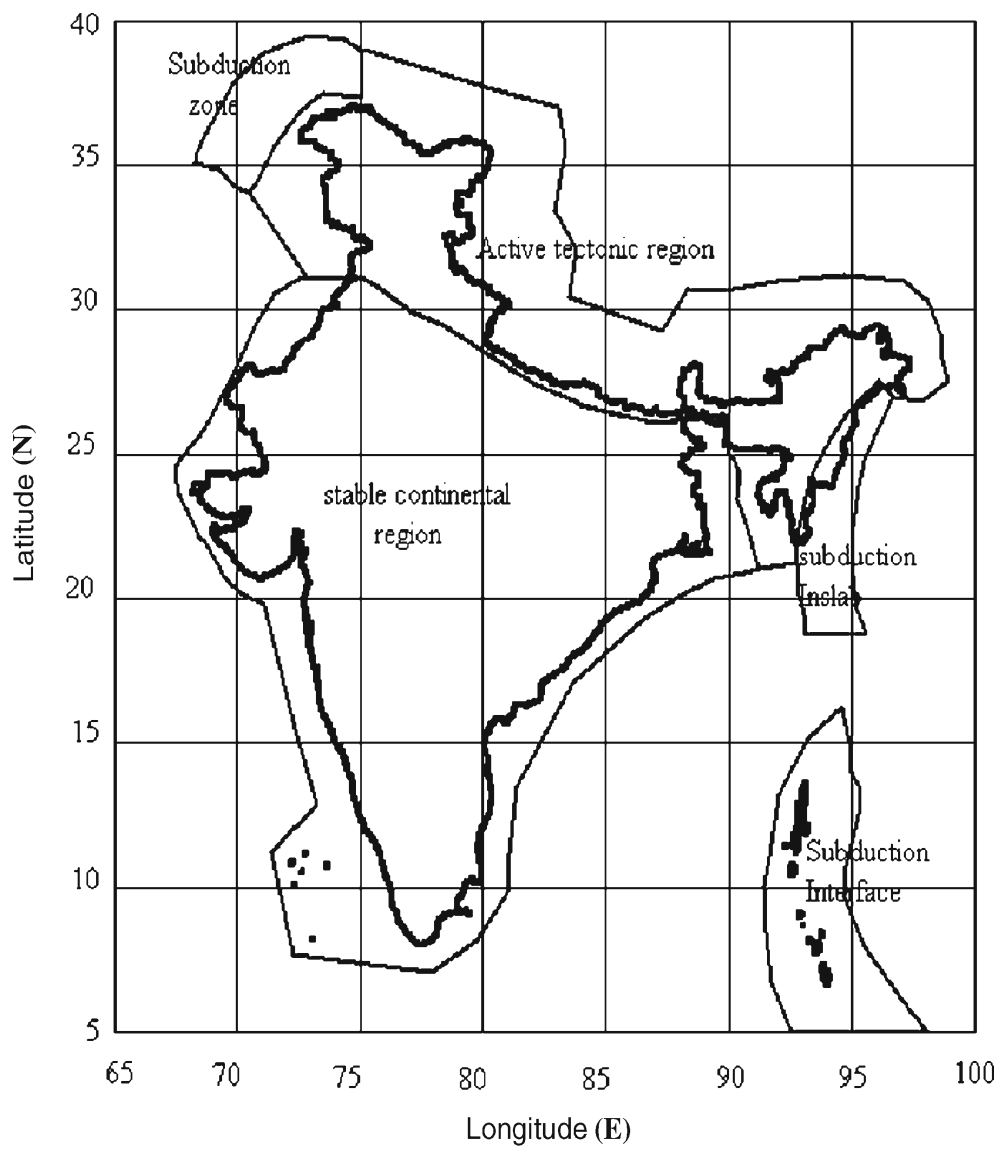

Figure 1. Tectonic provinces in and around India (after Gupta 2006; Nath and Thingbaijam 2010).

in the northeastern direction and its collision with the Eurasian plate has created the most gigantic mountain range of the world - the Himalayas with an average height of $4600 \mathrm{~m}$ and the biggest and highest plateau region in the world - the Tibetan Plateau. The Indian plate was considered as one of the fastest moving plates in the world. Before its collision with the Eurasian plate, it has attained very high velocity of around $20 \mathrm{~cm} /$ year (Kumar et al. 2007). The current movement of Indian plate is estimated to be around $5 \mathrm{~cm} /$ year. The collision and the subsequent formation of the Himalayas and the Tibetan Plateau are associated with very high seismicity.

The entire northeast region is put under Zone $\mathrm{V}$ of the Indian seismic zonation code (BIS-1893 2002). This region falls at the junction of $\mathrm{N}-\mathrm{S}$ trending Burmese Arc and E-W trending Himalayan Arc. Due to this, the entire region has suffered multiple phases of deformational processes and this has resulted in numerous geological structures (Sharma and Malik 2006).

\subsection{Subduction zones}

The subduction zones include that of HindukushPamir in the northwest frontier province, IndoMyanmar Arc, and Andaman-Sumatra seismic belt. The northeastern India, especially the region bordering China and Myanmar, is considered as the sixth most seismically active region in the world. The Indo-Burmese Arc is an important tectonic feature, the seismicity of which is related to the subduction of the Indian plate underneath the southeast Asian plate due to northeastward motion of India (Deshikachar 1974). The northeastern corner of India, sandwiched between the Himalayan and Burmese arcs, is characterized by a complex seismotectonic set-up and very high level of seismicity (Evans 1964). The earthquakes in this area are of intraslab in nature.

The Andaman Nicobar Islands, which is situated on the southeastern side of Indian landmass, consists of about 527 islands. The entire island chain is along the plate boundary between Indian plate and the Burmese plate. These regions come under subduction zones with interface earthquakes. This region is also put in Zone $\mathrm{V}$ of the Indian seismic zonation code (BIS-1893 2002). Lots of damaging earthquakes and Tsunami has hit the Andaman-Nicobar Islands in the past. The Sumatran earthquake of December 26, 2004 has also occurred along the same source and this region was one of the worst affected regions during the Tsunami. 


\subsection{Stable continental shield region}

Peninsular India is delineated as stable continental region (SCR) with low to moderate seismic activity (Chandra 1977). The seismicity of this region is of intraplate nature and appears to be associated with some local faults and weak zones (Rao and Murty 1970). The ENE-WSW trending Son-NarmadaTapti zone is a prominent tectonic province forming the northern margin of the peninsular shield of India. The major tectonic elements in the southern part of the peninsula can be listed as the massive Deccan Volcanic Province, the Southern Indian Granulite Terrain, the Dharwar Craton, the Cuddapah Basin, the Godavari and the Mahanadi Grabens, and the Eastern and Western Ghats on the east and west coasts, respectively (Gupta 2006). The researchers like Purnachandra Rao (1999), Gangrade and Arora (2000), Reddy (2003), etc. have highlighted the need for seismic study of southern peninsular India. The Bhuj earthquake (26 January 2001; causality around 19,000) and Latur earthquake (30 September 1993; causality around 7928) are the deadliest earthquakes in this region. There were about 10 earthquakes with magnitude 6.0 and above reported in this region.

\section{Earthquake database}

A comprehensive earthquake catalogue is a prerequisite for hazard estimation. In the present analysis, the historical part of earthquake catalogue was compiled from the work of Oldham (1883), Basu (1964), Kelkar (1968), Tandon and Srivastava (1974), Rastogi (1974), Chandra (1977, 1978), Kaila and Sarkar (1978), Rao and Rao (1984), Srivastava and Ramachandran (1985), Biswas and Dasgupta (1986), Guha and Basu (1993), Bilham (2004), etc. The instrumental catalogue was compiled from various national and international agencies like Bhabha Atomic Research Centre (BARC), India Meteorological Department (IMD), Indira Gandhi Centre for Atomic Research (IGCAR), Kalpakkam, National Geophysical Research Institute (NGRI) Hyderabad, International Seismological Center (ISC) data file, Harvard seismology and

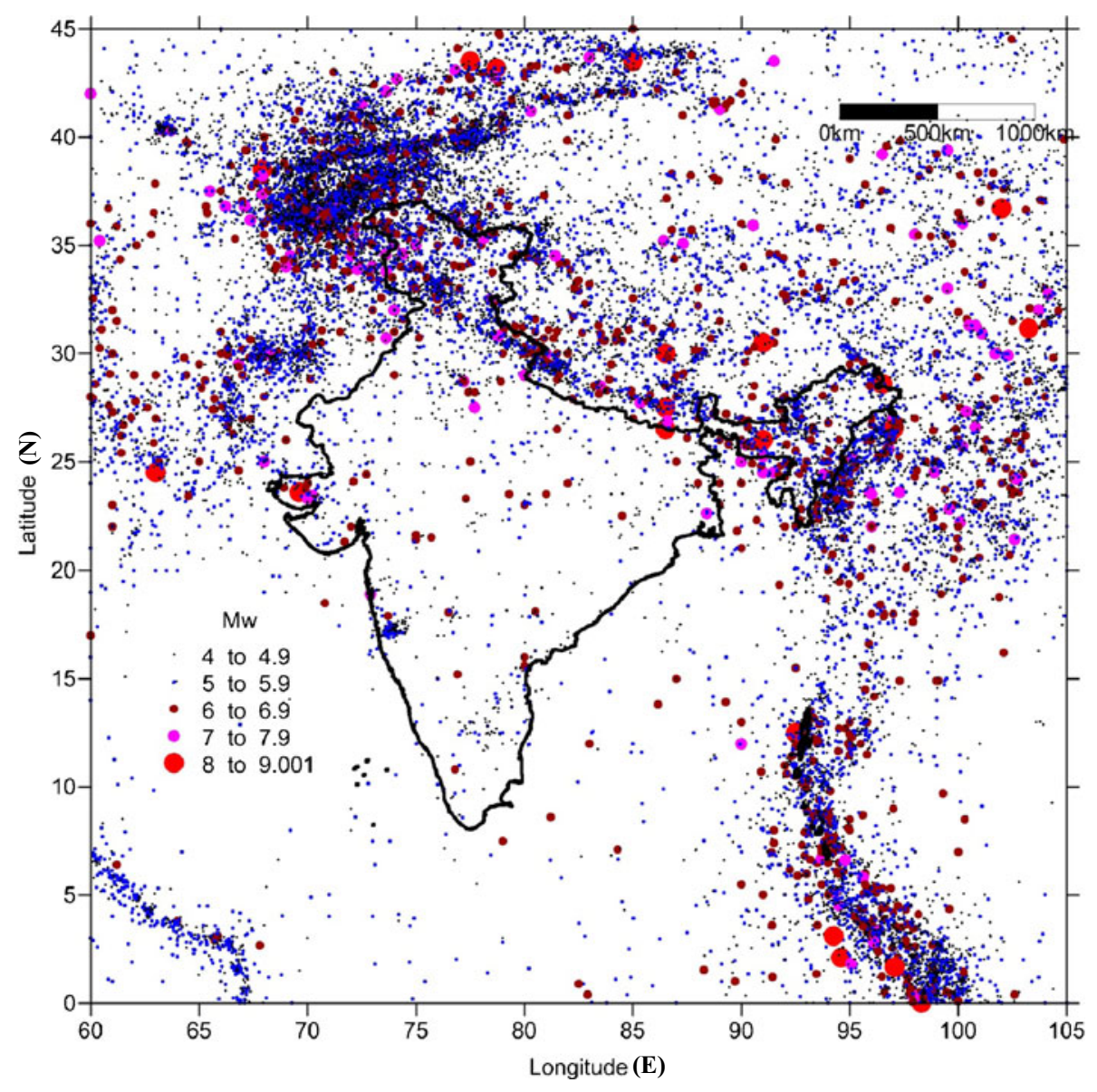

Figure 2. Distribution of earthquake events (mainshocks only) in and around India. 
USGS/NEIC catalogue. The details of the past earthquakes were collected from an area which extends up to $500 \mathrm{~km}$ from the boundary of India.

\subsection{Unification of the magnitude scale}

The magnitude scales of earthquake events in the catalogue may not be uniform. Most of the historic events were in the Intensity (I) scale and instrumental data were reported in body wave magnitude $\left(m_{b}\right)$, surface wave magnitude $\left(M_{S}\right)$, local magnitude $\left(\mathrm{M}_{\mathrm{L}}\right)$ or moment magnitude $\left(\mathrm{M}_{\mathrm{W}}\right)$. The moment magnitude scale is the most widely used as the moment magnitude scale does not saturate. Lots of empirical relations are available to convert different magnitude scales to $\mathrm{M}_{\mathrm{W}}$. Several relations were proposed by different researchers to convert different magnitude scales to $\mathrm{M}_{\mathrm{W}}$ (Gutenberg and Richter 1956; Heaton et al. 1986; Johnston 1996; Engdahl et al. 1998; Shedlock 1999; Papazachos et al. 2002; Scordilis 2006). In a recent work, Kolathayar et al. (2011) developed linear relations connecting various magnitude scales with moment magnitude scale, using the data collected from India and neighbouring areas. As it is always advisable to use the region-specific magnitude conversion relations (Liu et al. 2007), the region-specific correlations developed by Kolathayar et al. (2011) were used for homogenization of different magnitude scales.

\subsection{Declustering of the catalogue}

In estimating the earthquake hazard, generally, a Poisson model of earthquake occurrence is assumed. The instrumental catalogues involve lot of aftershocks and foreshocks along with the mainshocks. Aftershocks and foreshocks show a major deviation from a Poisson process and several methods have been suggested for the separation of aftershocks from the raw earthquake data (Savage 1972; Gardner and Knopoff 1974; Reasenberg 1985; Davis and Frohlich 1991; Molchan and Dmitrieva 1992). Deleting aftershocks and other dependent events leads approximately to a Poisson, or random dataset for a better estimation of return periods of randomly occurring events which is an important goal of seismic hazard studies. Declustering is the separation of the dependent events (i.e., foreshocks, aftershocks and clusters) from the background seismicity (Reasenberg 1985). In the present study, dependent shocks as those falls within the space and time intervals of the main shock are eliminated to obtain a dataset of mainshocks which are assumed to show a Poisson distribution.
Table 1. Details of major earthquakes $\left(M_{W}>7.5\right)$ occurred in and around India.

\begin{tabular}{|c|c|c|c|c|c|}
\hline & Month & Date & $\begin{array}{l}\text { Longitude } \\
\left({ }^{\circ}\right)\end{array}$ & $\begin{array}{l}\text { Latitude } \\
\qquad\left(^{\circ}\right)\end{array}$ & $\mathrm{M}_{\mathrm{W}}$ \\
\hline 1668 & 5 & 1 & 68 & 25 & 7.6 \\
\hline 1737 & 5 & 11 & 88.4 & 22.6 & 7.7 \\
\hline 1816 & 5 & 26 & 86.5 & 30 & 8 \\
\hline 1819 & 6 & 16 & 69.6 & 23.6 & 8.3 \\
\hline 1833 & 8 & 26 & 86.5 & 27.5 & 8 \\
\hline 1897 & 6 & 12 & 91 & 26 & 8.1 \\
\hline 1902 & 8 & 22 & 77 & 40 & 8.5 \\
\hline 1902 & 8 & 30 & 71 & 37 & 7.7 \\
\hline 1905 & 4 & 4 & 76 & 33 & 7.8 \\
\hline 1908 & 10 & 23 & 70.5 & 36.5 & 7.6 \\
\hline 1908 & 12 & 12 & 97 & 26.5 & 8.2 \\
\hline 1911 & 7 & 4 & 70.5 & 36.5 & 7.6 \\
\hline 1916 & 8 & 28 & 81 & 30 & 7.7 \\
\hline 1918 & 7 & 8 & 91 & 24.5 & 7.6 \\
\hline 1921 & 11 & 15 & 70.5 & 36.5 & 8.1 \\
\hline 1931 & 1 & 27 & 96.8 & 25.6 & 7.6 \\
\hline 1932 & 12 & 25 & 96.5 & 39.2 & 7.6 \\
\hline 1934 & 1 & 15 & 86.5 & 26.5 & 8.1 \\
\hline 1937 & 1 & 7 & 98 & 35.5 & 7.6 \\
\hline 1941 & 6 & 26 & 92.5 & 12.5 & 8.5 \\
\hline 1947 & 3 & 17 & 99.5 & 33 & 7.7 \\
\hline 1949 & 3 & 4 & 70.6 & 36.6 & 7.7 \\
\hline 1950 & 8 & 15 & 96.5 & 28.6 & 8.6 \\
\hline 1951 & 11 & 18 & 91 & 30.5 & 8 \\
\hline 1956 & 6 & 9 & 69.1 & 34.3 & 7.6 \\
\hline 1965 & 3 & 14 & 70.8 & 36.6 & 7.8 \\
\hline 1983 & 12 & 30 & 72 & 34.5 & 7.7 \\
\hline 1988 & 11 & 6 & 99.6 & 22.8 & 7.6 \\
\hline 1997 & 11 & 8 & 87.325 & 35.069 & 7.6 \\
\hline 2001 & 1 & 26 & 70.232 & 23.419 & 7.7 \\
\hline 2001 & 11 & 14 & 90.541 & 35.946 & 7.8 \\
\hline 2004 & 12 & 26 & 94.26 & 3.09 & 9 \\
\hline 2005 & 10 & 8 & 73.588 & 34.539 & 7.6 \\
\hline
\end{tabular}

The declustering was done following the algorithm developed by Gardner and Knopoff (1974) modified by Uhrhammer (1986). Out of 203,448 events in the raw catalogue, 50,317 events were identified as mainshocks of which 27,146 events were of $\mathrm{M}_{\mathrm{W}} \geq 4$. The distribution of earthquake events $\left(\mathrm{M}_{\mathrm{W}} \geq 4\right)$ in the declustered catalogue is shown in figure 2. The details of major earthquakes in the region are listed in table 1.

\section{Seismic source models}

Another important step in the seismic hazard analysis is the identification of vulnerable seismic sources. The different types of seismic sources 
considered in the present study are linear seismic sources and point sources.

\subsection{Linear seismic sources}

The major tectonic features with which the past seismic activity in India could be associated are well known at present. One of the best documents listing the linear seismic sources in India and adjoining areas is the Seismotectonic Atlas (Dasgupta et al. 2000) published by the Geological Survey of India (GSI). The Seismotectonic Atlas (SEISAT) was prepared after extensive studies using remote sensing technique and by geological explorations. The SEISAT maps are available in $\mathrm{A}_{0}$ size sheets with 1:1,000,000 scale and each map covers an area of $3^{\circ} \times 4^{\circ}$. SEISAT contains the details of the faults, lineaments and shear zones in addition to the geological features in India and adjoining areas. This has been taken as an authentic reference manual for identifying the seismic sources by various researchers like, Iyengar and Ghosh (2004) for Delhi, Nath et al. (2006) for microzonation of Sikkim Himalayas, Raghu Kanth and Iyengar (2006) for Mumbai, Boominathan et al. (2008) for Chennai, Anbazhagan et al. (2009) for Bangalore and Vipin et al. (2009) for south India. In the present study also SEISAT was taken as the main reference for identifying the linear seismic sources. The linear seismic sources mentioned by Ganesha Raj and Nijagunappa (2004) and Gupta (2006) are also considered for the analysis.

All the 43 sheets of SEISAT were scanned using a high resolution scanner to digitize these maps. Then these individual maps were georeferenced using MapInfo Professional Version 6.0. After georeferencing, the individual maps (images) were combined together to form a complete map of India and adjoining areas. From this map the tectonic features were carefully extracted and these extracted data was kept as a separate layer. This extracted layer will consist of all the linear seismic sources identified by Dasgupta et al. (2000). Even though SEISAT lists lots of linear tectonic features, all of these may not be active seismic sources. In order to identify the active seismic sources, the earthquake data, which is having the magnitude and the epicentral parameters were superimposed on to the map having the tectonic features. This combined georeferenced map was studied very carefully and only those tectonic features which are associated with earthquakes of moment magnitude 4.0 and above were selected as active seismic sources. The linear sources selected after the above-mentioned process is shown in figure 3. All

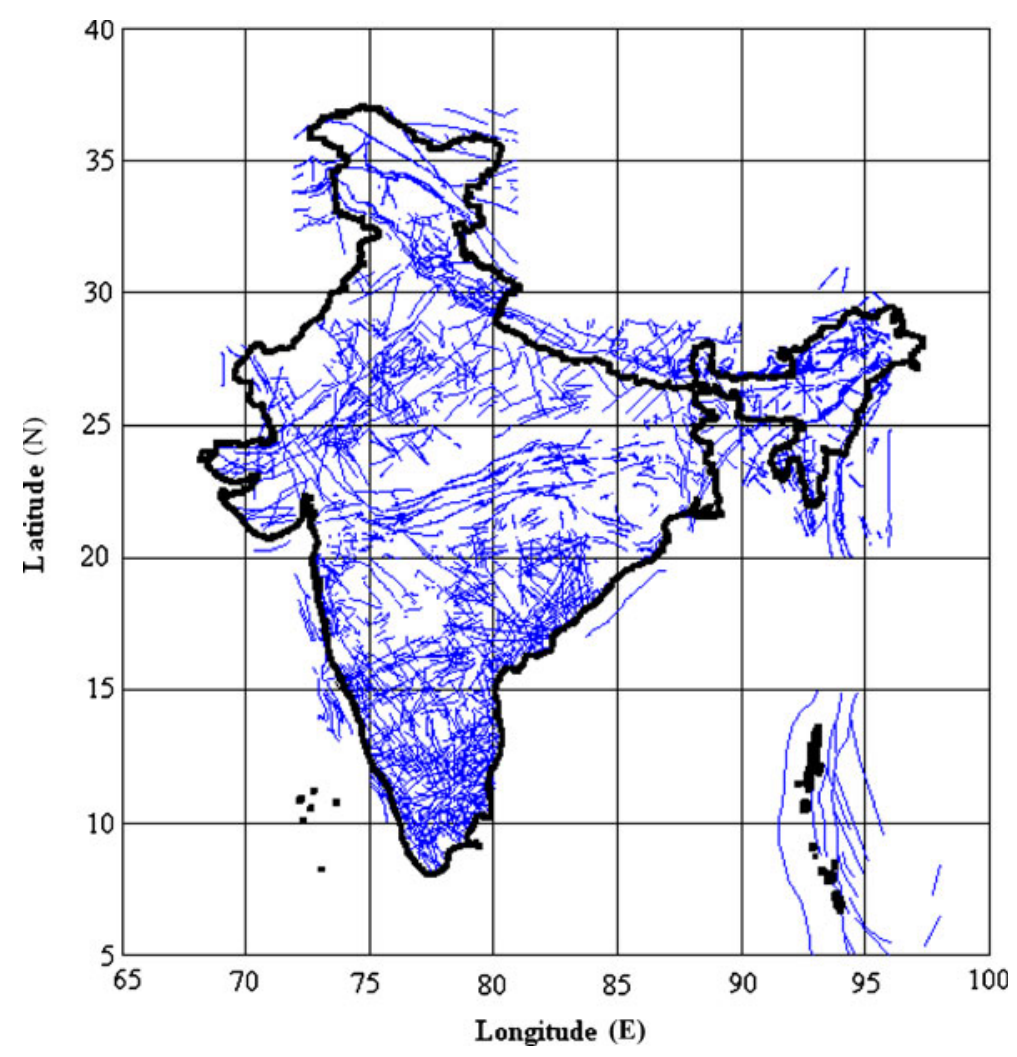

Figure 3. Linear seismic sources identified in India. 
the earthquake events were superimposed on the linear source map to develop the seismotectonic map for the country.

\subsection{Point sources}

Even though the linear seismic sources were identified from SEISAT and other literatures, it can be seen that there are lots of earthquake events which are not associated with any of the identified linear seismic sources. When the seismic hazard analysis is done using the linear seismic sources alone, the effects of such earthquake events will not be considered. This in turn will lead to a misleading interpretation of seismic hazard. In those cases the modelling of seismic sources as point sources, will be a better option. For identification of these sources, the study area was divided into grids of size $0.2^{\circ} \times 0.2^{\circ}$ and the maximum reported magnitude within each cell was allotted to the centre of that cell. After allotting the maximum magnitude to the centre of each grid for the entire study area, these observed maximum magnitudes were smoothed using a centered smoothing window. The smoothing is carried out to account for the source dimension and the location errors (Costa et al. 1993; Panza et al. 1999). Depending upon the magnitude of earthquake, the rupture length will vary and the smoothing will take into account this aspect. The radius of the smoothing windows selected were having radius of $0.2^{\circ}, 0.4^{\circ}$ and $0.6^{\circ}$ (radius of 1, 2 and 3 grids) for magnitude ranges of $4-4.9,5-5.9$ and $\geq 6$, respectively.

The smoothing process of the study area was done from the extreme south-western grid point (bottom - left grid). The centre of the smoothing window was kept on that grid point and its radius was selected based on the magnitude of earthquake in that grid. While smoothing, the earthquake magnitudes will be assigned only to those cells which are having number of earthquakes equal to or greater than a threshold value. Once the smoothing of that particular grid point is over, the centre of the smoothing window will be shifted to the adjoining grid point on the same row and the same process will be repeated. Smoothing of the earthquake magnitudes was done using a new program developed in MATLAB. During the smoothing process the program will keep in memory all the original magnitudes in each of the grid points. This is very essential because while smoothing it is not permissible to overwrite a larger magnitude with a smaller one. After completing the smoothing for a particular row, the centre of the smoothing window will be shifted to the next row and the process will be repeated till the smoothing of the entire study area is over. For seismic hazard analysis, only the events with magnitude equal to or greater than 4 were used.

\section{Estimation of hazard}

The deterministic seismic hazard approach (DSAH) considers a particular earthquake scenario, either realistic or assumed one. The DSHA approach uses known seismic sources which are near the site and available historical seismic and geological data to generate discrete, single-valued events or models of ground motion at the site. The earthquakes are assumed to occur on the source closest to the site. The deterministic seismic hazard analysis needs three input details like earthquake source, controlling earthquake at the source and an attenuation relation to evaluate the seismic hazard. In DSHA, the controlling earthquake is assumed to act along the source at the shortest distance from the site. For hazard estimation, each grid point was considered one by one. At a particular grid point, all the linear sources within the radius of $300 \mathrm{~km}$ were considered and expected PGA value was estimated for each of these sources by considering closest possible distance and maximum earthquake associated with that source. All the earthquake events close to each linear source were studied and the maximum observed magnitude among those events was considered as the maximum magnitude event associated with that source. While calculating the minimum distance, the focal depth and the curvature of earth were also considered. The distance type specific to each attenuation relation has been considered in the analysis while estimating PGA using different attenuation models. The source which gives highest value of PGA has the maximum earthquake potential and that PGA is considered for that grid point. This exercise is repeated for each grid point using all the attenuation relations. The uncertainties involved in the earthquake magnitude or location are not taken into account and this method will give an upper bound value for the ground motion. Hence DSHA method is adopted in evaluation of seismic hazard for some of the critical structures like nuclear power plants, big dams, bridges, hazardous waste contaminant facilities, etc.

\subsection{Attenuation models}

The seismicity of Indian subcontinent is spatially varied and complex as it embraces various tectonic zones with different attenuation characteristics. The north and northwest India are active tectonic regions with shallow crustal seismic activity. The seismic activity in Indo-Myanmar subduction zone 
in northeast India is because of intraslab subduction earthquakes. The Andaman Nicobar regions also come under subduction zone, but with earthquakes of interface nature. The south and central India are stable continental regions with low-tomoderate seismicity. Different attenuation relations should be used for these regions. Hence for the selection of Ground Motion Prediction Equations (GMPE), the study area was divided into four categories - active tectonic shallow crustal region, stable continental region, subduction intraslab region and subduction interface region.

In India, there is lack of strong motion data and this in turn has resulted in the development of only very few region specific GMPEs. Some of the important GMPE available for India are Sharma (1998) for Himalayan region, Iyengar and Ghosh (2004) for Delhi region; Raghu Kanth and Iyengar (2007) for peninsular India; Nath et al. (2005) for Sikkim Himalaya; Nath et al. (2009) for Guwhati and Sharma et al. (2009) for Himalayan region. Out of these attenuation relations, the most widely used relations are Raghu Kanth and Iyengar (2007) and Sharma et al. (2009). Since only a few attenuation relations were available for the study area, in the present study we have used some of the well accepted GMPEs, which were developed for other regions of the world which are having similar seismic attenuation characteristics. In a recent study, Nath and Thingbaijam (2010) reviewed the ground motion prediction in Indian scenario with reference to existing GMPEs developed for different tectonic environments and those employed by different regional hazard studies.

In the present analysis, three different GMPEs, each were used to model the attenuation properties of the plate boundary region, shield region and intraslab subduction zones. The relations used for shield region are Campbell and Bozorgnia (2003), Atkinson and Boore (2006) and Raghu Kanth and Iyengar (2007). Out of these, the relation by Raghu Kanth and Iyengar (2007) was developed for the peninsular Indian shield regions. Raghu Kanth and Iyengar (2007) observed that their model have predictions similar to those of the available models for other intraplate regions. Attenuation relations given by Campbell and Bozorgnia (2003) and Atkinson and Boore (2006) were developed for the eastern North America (ENA). Based on the study of aftershocks of Bhuj earthquake, Cramer and Kumar (2003) came to the conclusion that the ground motion attenuation in ENA and peninsular Indian shield are comparable. Similarity of the regional tectonics of ENA and peninsular India has also been noted by Bodin et al. (2004).

The GMPEs used for active tectonic regions are Boore and Atkinson (2008), Sharma et al. (2009) and Akkar and Bommer (2010). Of these, the relation suggested by Sharma et al. (2009) was developed for Himalayan regions of India. Sharma et al. (2009) used data from the Himalayas and Zagros regions on the premises that seismotectonics of the two regions have considerable similarity (Ni and Barazangi 1986). On the other hand, the relation by Boore and Atkinson (2008) was developed for active tectonic regions across the world and Akkar and Bommer (2010) was developed for the active tectonic regions of Europe and Middle East.

Subduction zone earthquakes are characterized by different attenuation characteristics compared to the shallow crustal earthquakes (Abrahamson and Silva 1997). Youngs et al. (1997) developed separate attenuation relations for the ground motion due to intraslab and interface earthquakes in subduction zone using a global database of about 350 horizontal acceleration components. Atkinson and Boore (2003) updated these relationships using a much bigger worldwide database of about 1200 horizontal acceleration components. Gupta (2010) analyzed a limited number of strong-motion data recorded in northeast Indian region, and concluded that the intraslab earthquakes along the IndoBurmese subduction zone are found to be characterized by much larger ground motion amplitudes than that for the earthquakes along other subduction zones around the world. Gupta (2010) modified attenuation relations developed by Atkinson and Boore (2003) using a global database for subduction zone earthquakes to be more appropriate for the northeast India. For Indo-Myanmar subduction zone, we used the attenuation relations suggested by Gupta (2010), Zhao et al. (2006) and Lin and Lee (2008) as all the three are capable of predicting ground motion from intraslab subduction earthquakes. For the subduction zone with interface earthquakes, the GMPEs used were of Gregor et al. (2002), Atkinson and Boore (2003) and Lin and Lee (2008). The GMPE by Gupta (2010) is developed specifically for Indo-Myanmar subduction zone whereas GMPEs by Zhao et al. (2006) and Lin and Lee (2008) were developed for the subduction regions (both intraslab and interface) of Japan and Taiwan, respectively. Attenuation relations given by Gregor et al. (2002) and Atkinson and Boore (2003) were developed for Cascadia subduction zone. The GMPE models for different sesismotectonic provinces considered in the present study are summarized in table 2 .

\subsection{Logic tree structure}

There are lots of uncertainties involved in models used for seismic hazard assessment and this makes 
Table 2. Attenuation relations used for different tectonic provinces of Indian region.

\begin{tabular}{llll}
\hline & & \multicolumn{2}{c}{ Subduction zone } \\
\cline { 3 - 4 } Shield region & Active tectonic regions & Intraslab region & Interface region \\
\hline Atkinson and Boore (2006) & Sharma et al. (2009) & Zhao et al. (2006) & Gregor et al. (2002) \\
Raghu Kanth and Iyengar (2007) & Boore and Atkinson (2008) & Lin and Lee (2008) & Atkinson and Boore (2003) \\
Campbell and Bozorgnia (2003) & Akkar and Bommer (2010) & Gupta (2010) & Lin and Lee (2008) \\
\hline
\end{tabular}

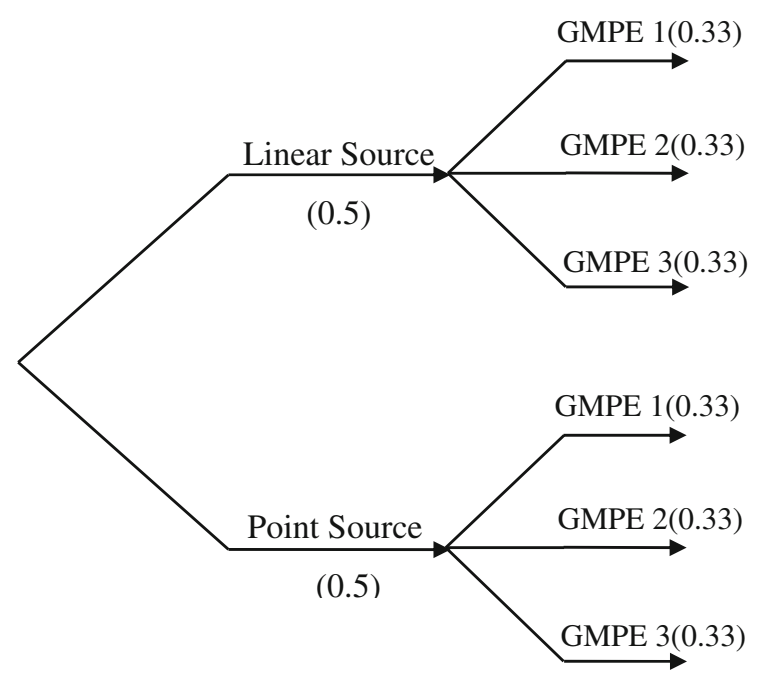

Figure 4. Parameters and weighing factors adopted in the logic tree.

the selection of a seismic hazard model difficult. The use of logic tree approach allows a characterization of epistemic uncertainties in various models by including alternative models in the analysis (Stepp 1972; Budnitz et al. 1997; Bommer et al. 2005). Logic tree consists of a series of nodes and branches and these branches denote different models (hypothesis). A subjective weightage, based on engineering judgement, can be given to each of these branches depending on the likelihood of being correct. The weightage for all the branches at a particular node should be equal to unity. The weightage of the terminal branch of the logic tree can be obtained by multiplying the weightage of all the branches leading to it. The present study considers two types of source models and three different attenuation relations each for various tectonic provinces in the study area. Equal weightages have been assigned to each of the source models as a predefined criterion is not available for assigning the weightages. As regards GMPEs also, it was difficult to assign a higher weightage to one equation over the other, and hence equal weightages have been chosen. These different models were combined using the logic tree. The logic tree branch with the weightage assigned to each model is shown in figure 4.

\section{Results and discussions}

The seismic hazard analysis of India was done by dividing the entire country into grids of size $0.1^{\circ} \times 0.1^{\circ}$ (about $11 \times 11 \mathrm{~km}$ ). The total number of grid points considered for the analysis was 58,351 . For each grid point the peak ground acceleration (PHA) and spectral acceleration (Sa) (for periods of $0.1 \mathrm{~s}$ and $1 \mathrm{~s}$ ) values were evaluated for bed rock level with a deterministic approach using a code written in MATLAB. For each grid point, all the sources within a radius of $300 \mathrm{~km}$ were considered for evaluation of PHA and Sa values. For the plate boundary regions, since the earthquake magnitudes were higher, this distance was increased to $400 \mathrm{~km}$. The PHA values obtained for five most populous cities (Mega cities and Metros) of India are given in table 3 . The spatial variation of PHA values obtained is shown in figure 5 . The spectral acceleration values for the periods $0.1 \mathrm{~s}$ and $1 \mathrm{~s}$ obtained are shown in figures 6 and 7 .

It can be seen that the seismic hazard is high along the plate boundary regions, viz., north and northeast India and Andaman-Nicobar Islands. Along the shield region, the highest hazard is observed at Bhuj region and at Koyna region. The PHA value for plate boundary regions varies from 0.3 to $0.5 \mathrm{~g}$ whereas for shield region the values were less than $0.25 \mathrm{~g}$ except for Kuch region in Gujarat. The Indian seismic code BIS-1893 (2002) divides the country into four zones, viz., Zones II, III, IV and V. The maximum expected accelerations in each of these zones are $0.1,0.16$, 0.24 and $0.36 \mathrm{~g}$, respectively. The PHA values obtained in this study for northeast India and most parts of Jammu and Kashmir are higher than what is specified by BIS-1893 (2002).

The only previous DSHA study of entire India was done by Parvez et al. (2003). For source modelling, they have defined 40 seismogenic zones for the Indian subcontinent which were classified on the basis of seismicity, tectonics and geodynamics; 
Table 3. PGA values at rock level for five most populous cities of India.

\begin{tabular}{|c|c|c|c|c|c|}
\hline \multirow[b]{2}{*}{ Major cities } & \multicolumn{2}{|c|}{ Location } & \multicolumn{2}{|c|}{ PGA value $(\mathrm{g})$} & \multirow{2}{*}{$\begin{array}{c}\text { Zone factor } \\
\text { reported by } \\
\text { BIS-1893 (2002) }\end{array}$} \\
\hline & $\begin{array}{c}\text { Longitude } \\
\left({ }^{\circ} \mathrm{E}\right)\end{array}$ & $\begin{array}{c}\text { Latitude } \\
\left({ }^{\circ} \mathrm{N}\right)\end{array}$ & $\begin{array}{c}\text { Present } \\
\text { value }\end{array}$ & $\begin{array}{c}\text { Parvez et al. } \\
(2003)\end{array}$ & \\
\hline Mumbai & 72.82 & 18.90 & 0.27 & Not reported & 0.16 \\
\hline New Delhi & 77.20 & 28.58 & 0.38 & $0.15-0.30$ & 0.24 \\
\hline Bengaluru & 77.59 & 12.98 & 0.10 & Not reported & 0.1 \\
\hline Kolkata & 88.33 & 22.53 & 0.30 & $0.01-0.02$ & 0.16 \\
\hline Chennai & 80.25 & 13.07 & 0.1 & Not reported & 0.16 \\
\hline
\end{tabular}

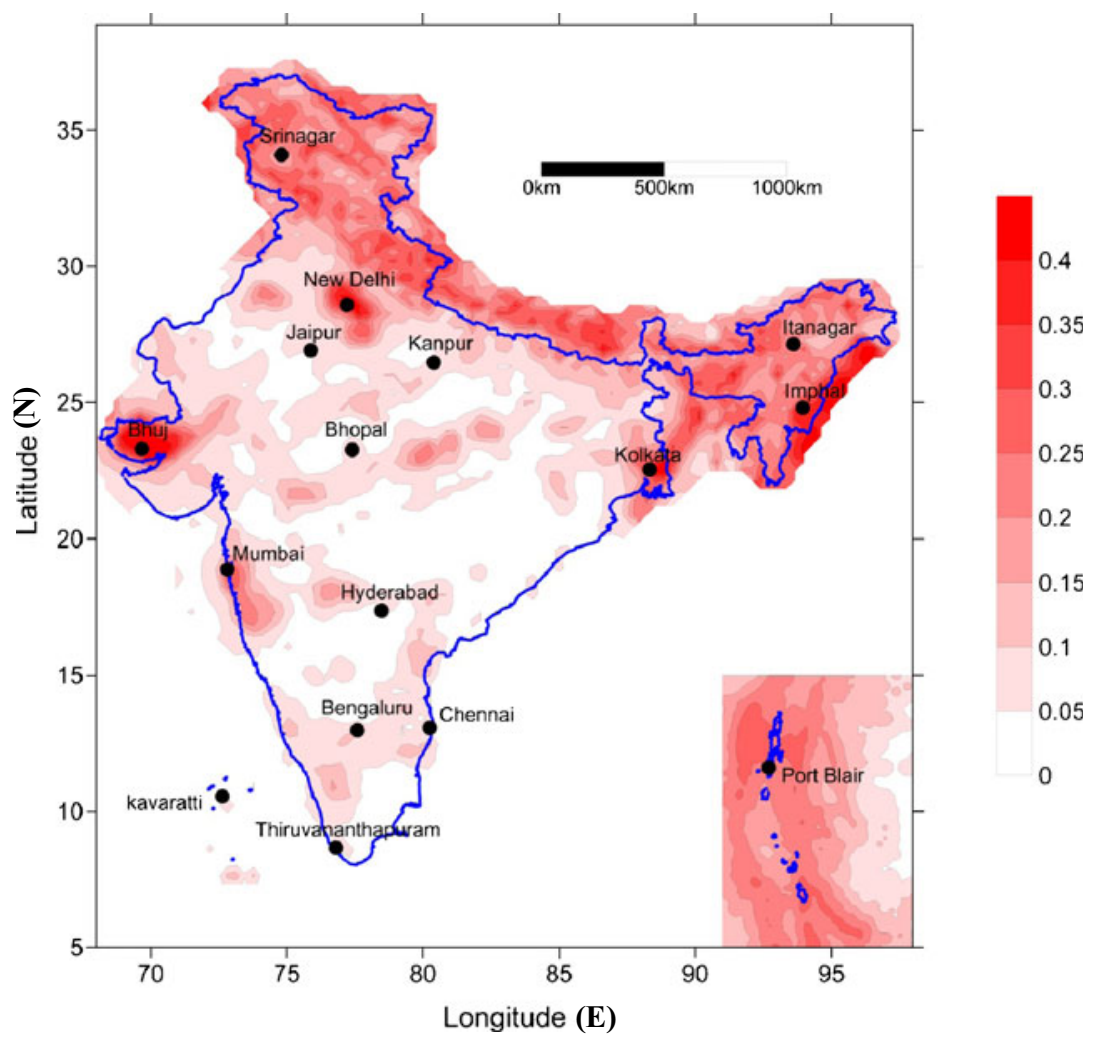

Figure 5. Spatial variation of peak ground acceleration value (g) at bed rock level in and around India.

whereas in the present study, we used identified linear sources and smoothed point sources. The hazard estimation by Parvez et al. (2003) was based on synthetic strong ground motion modelling whereas the present study employed recognized attenuation relations corresponding to different tectonic provinces. The PHA values obtained in the present study for Delhi, Kutch region and northeast India are in good agreement with those obtained by Parvez et al. (2003) whereas the present PHA values for many other parts of the country especially peninsular shield are higher than those reported by them. The comparison of present PHA values with those of Parvez et al. (2003) for important cities are also shown in table 3. It is to be noted that Parvez et al. (2003) have not reported the PHA value for many parts of peninsular shield. Present PHA values for low seismic regions are matching with the values reported by Vipin and Sitharam (2010).

For the purpose of comparison and evaluation, the PHA values were estimated without the use of logic tree approach which is also shown in figure 8 . For the same, point source model was employed along with GMPEs given by Atkinson and Boore (2006), Sharma et al. (2009), Gupta (2010) and Gregor et al. (2002). It is seen that point source model predicts high hazard in and around the location of earthquakes whereas linear source model predicts the same along the whole length of a tectonic feature associated with an earthquake. 


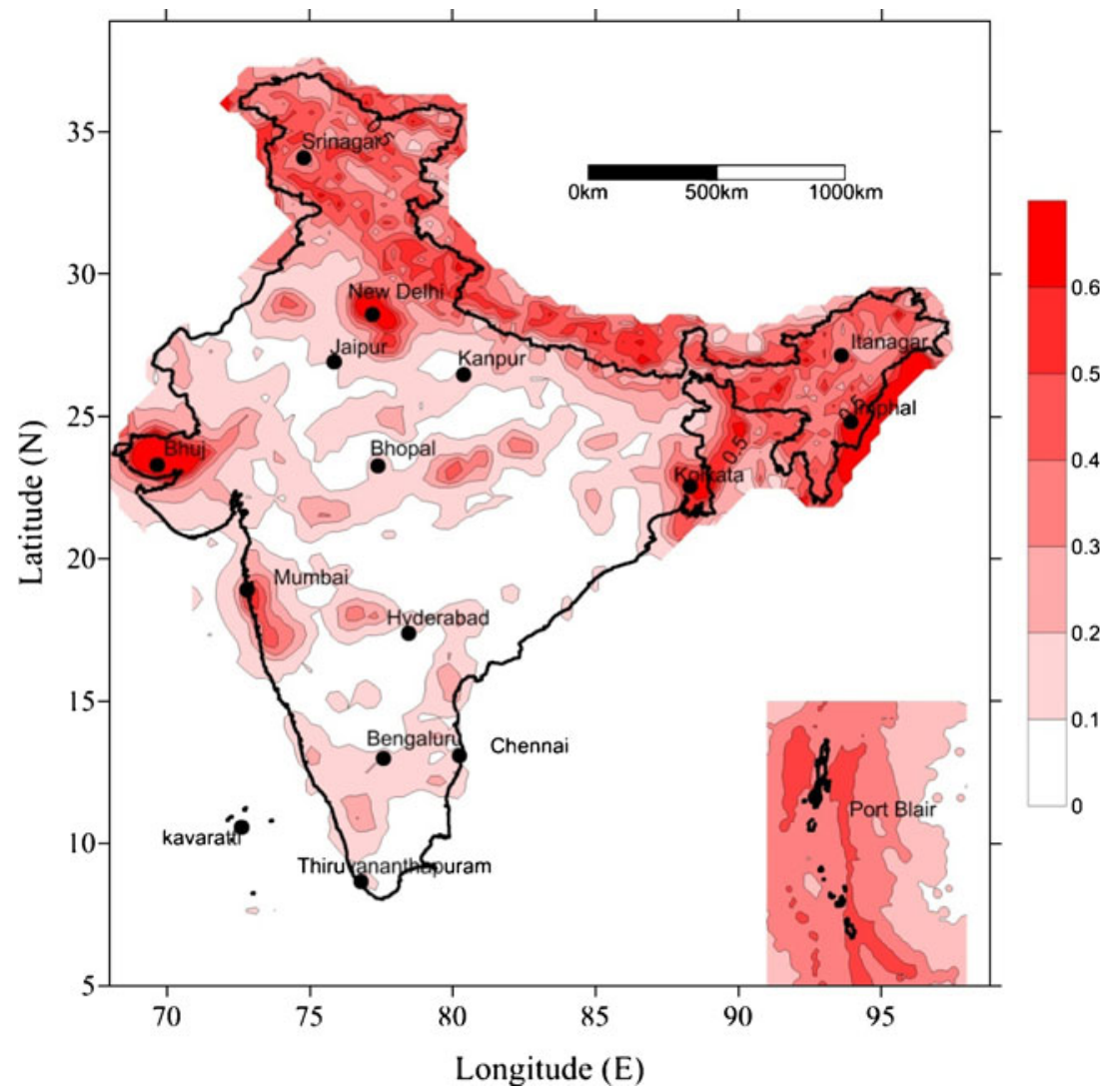

Figure 6. Spatial variation of peak spectral acceleration $(\mathrm{g})$ for $0.1 \mathrm{~s}$ at bed rock level in and around India.

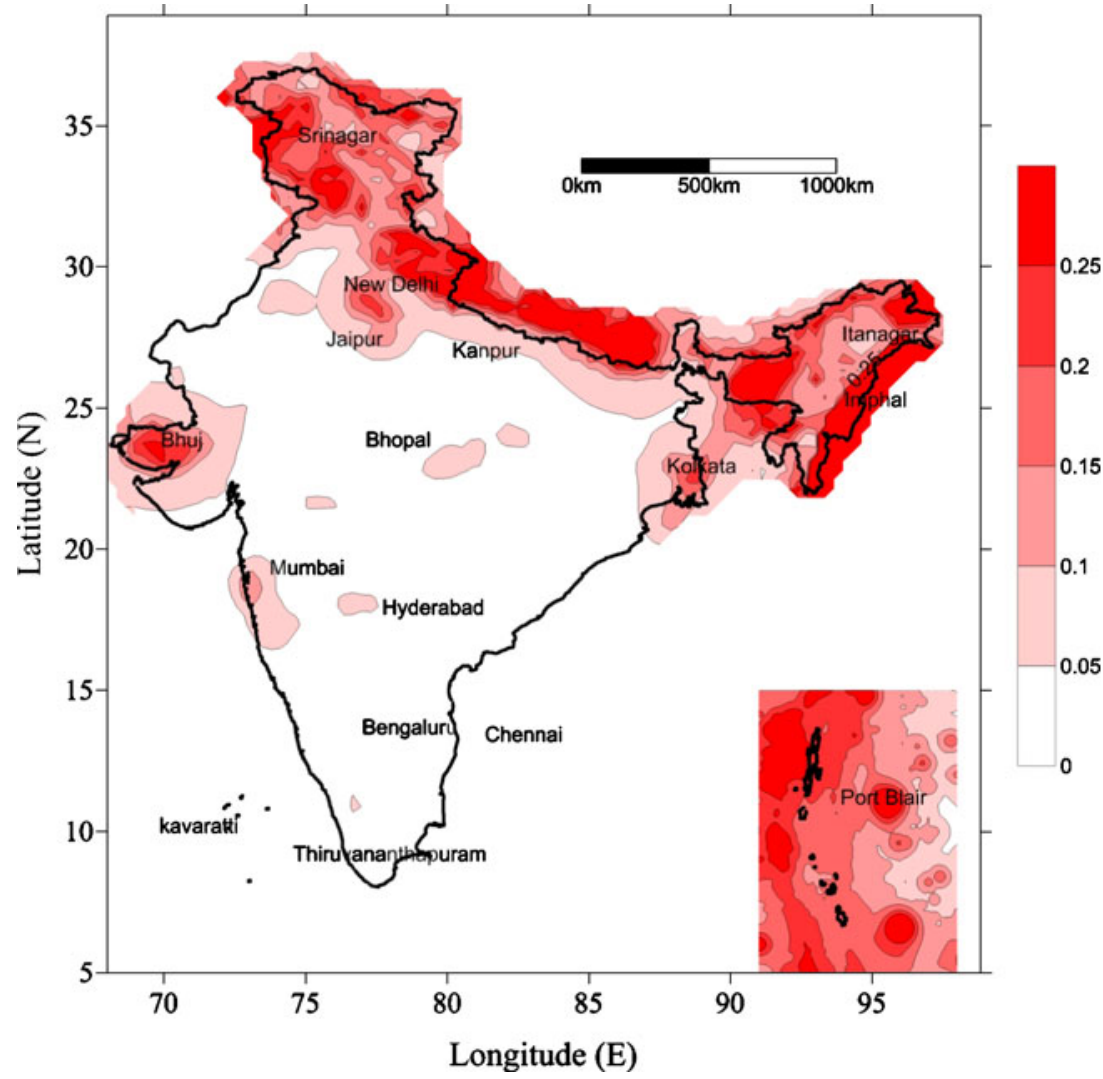

Figure 7. Spatial variation of peak spectral acceleration $(\mathrm{g})$ for $1 \mathrm{~s}$ at bed rock level in and around India. 


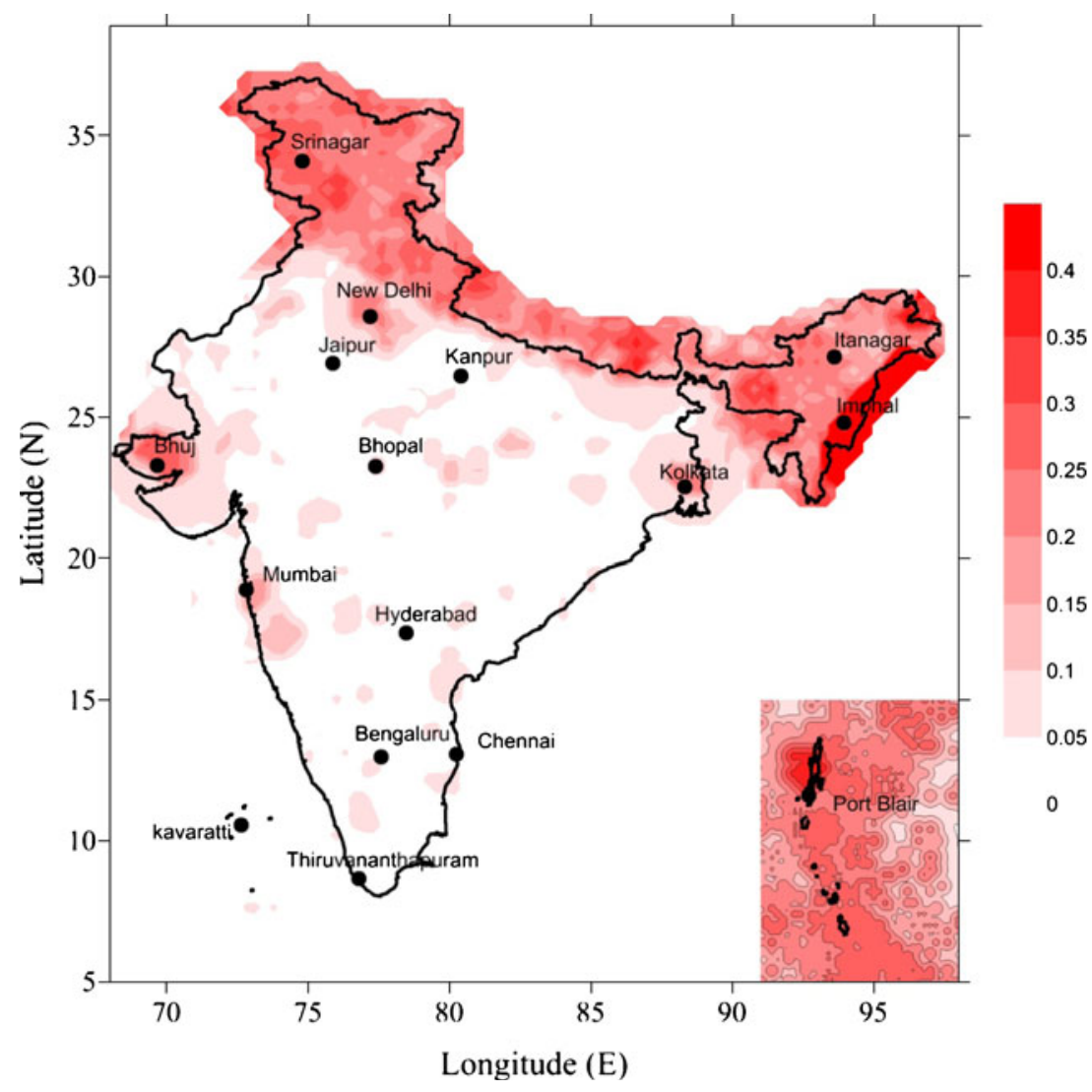

Figure 8. Spatial variation of peak ground acceleration value (g) at bed rock level without the use of logic tree.

\section{Conclusions}

The seismic hazard evaluation of the Indian landmass based on a state-of-the-art DSHA study has been performed using different source models and attenuation relations. The most recent knowledge on seismic activity in the region has been used to evaluate the hazard incorporating uncertainty associated with different modelling parameters as well as spatial and temporal uncertainties. The DSHA has been performed with currently available data and their best possible scientific interpretation using an appropriate instrument such as the logic tree to explicitly account for epistemic uncertainty by considering alternative models (source models and ground motion prediction equations).

The hazard maps have been produced for horizontal ground motion on bed rock level (Shear wave velocity $\geq 3.6 \mathrm{~km} / \mathrm{s}$ ) and compared with the seismic hazard zoning map by the Indian seismic standards (IS: 1893 part 1, 2002, which is based on intensity and geological data; not based on a scientific seismic hazard assessment) and Parvez et al. (2003). The present study shows that the seismic hazard is moderate in peninsular shield (except Kutch region of Gujarat), but the hazard in the north and northeast India and Andaman-Nicobar region are very high. The PHA values obtained in this study for most parts of the country are higher than what is specified by BIS-1893 (2002). The ground motion predicted from the present study not only aids in safe design of structures, but also helps in deciding the locations of important structures such as nuclear power plants.

\section{Acknowledgements}

Authors would like to acknowledge IMD, BARC, USGS, ISC, IRIS and NGRI for providing the details of earthquake events in the Indian subcontinent. Authors are thankful to Centre for Infrastructure and Sustainable Transportation, Indian Institute of Science, Bangalore for providing necessary GIS tools and support for the present work. The authors thank the anonymous reviewers for their valuable comments towards improving the quality of the manuscript.

\section{References}

Abrahamson N A and Silva W J 1997 Empirical response spectral attenuation relations for shallow crustal earthquakes; Seismol. Res. Lett. 68 94-127.

Akkar S and Bommer J J 2010 Empirical equations for the prediction of PGA, PGV, and spectral accelerations in 
Europe, the Mediterranean region, and the Middle East; Seismol. Res. Lett. 81 195-206.

Anbazhagan P, Vinod J S and Sitharam T G 2009 Probabilistic seismic hazard analysis for Bangalore; J. Natural Hazards 48 145-166.

Atkinson G M and Boore D M 2003 Empirical groundmotion relations for subduction-zone earthquakes and their application to Cascadia and other regions; Bull. Seismol. Soc. Am. 93 1703-1729.

Atkinson G M and Boore D M 2006 Earthquake groundmotion prediction equations for Eastern North America; Bull. Seismol. Soc. Am. 96(6) 2181-2205.

Basu K L 1964 A note on the Coimbatore earthquake of 8th February 1900; Indian J. Meteorol. Geophys. 15(2) $281-286$.

Bilham R 2004 Earthquakes in India and the Himalaya: Tectonics, geodesy and history; Ann. Geophys. 47 839-858.

BIS-1893 2002 Indian Standard criteria for earthquake resistant design of structures, Part 1 - General provisions and buildings; Bureau of Indian Standards, New Delhi.

Biswas S and Dasgupta A 1986 Some observations on the mechanism of earthquakes in the Himalaya and the Burmese arc; Tectonophys. 122 325-343.

Bodin P, Malagnini L and Akinci A 2004 Ground-motion scaling in the Kachchh Basin, India, deduced from aftershocks of the $2001 \mathrm{Mw}$ 7.6 Bhuj Earthquake; Bull. Seismol. Soc. Am. 94 1658-1669.

Bommer J J, Scherbaum F, Bungum H, Cotton F, Sabetta F and Abrahamson N A 2005 On the use of logic trees for ground-motion prediction equations in seismic hazard analysis; Bull. Seismol. Soc. Am. 95 377-389.

Boominathan A, Dodagoudar G R, Suganthi A and Uma Maheswari R 2008 Seismic hazard assessment of Chennai city considering local site effects; J. Earth Syst. Sci. 117 853-863.

Boore D M and Atkinson G M 2008 Ground-motion prediction equations for the average horizontal component of PGA, PGV, and 5\%-damped PSA at spectral periods between $0.01 \mathrm{~s}$ and $10.0 \mathrm{~s}$; Earthquake Spectra 24 99-138.

Budnitz R J, Apostolakis G, Boore D M, Cluff L S, Coppersmith K J, Cornell C A and Morris P A 1997 Recommendations for probabilistic seismic hazard analysis: Guidance on uncertainty and use of experts; U.S. Nuclear Regulatory Commission Report, NUREG/CR- 6372.

Campbell K W and Bozorgnia Y 2003 Updated near-source ground motion (attenuation) relations for the horizontal and vertical components of peak ground acceleration and acceleration response spectra; Bull. Seismol. Soc. Am. 93 314-331.

Chandra U 1977 Earthquakes of peninsular India - a seismotectonic study; Bull. Seismol. Soc. Am. 67 1387-1413.

Chandra U 1978 Seismicity, earthquake mechanisms along the Himalayan mountain range and vicinity; Phys. Earth Planet. Int. 16 109-131.

Costa G, Panza G F, Suhadolc P and Vaccari F 1993 Zoning of the Italian territory in terms of expected peak ground acceleration derived from complete synthetic seismograms; J. Appl. Geophys. 30 149-160.

Cramer C H and Kumar A 20032001 Bhuj, India, earthquake engineering seismoscope recordings and eastern North America ground motion attenuation relations; Bull. Seismol. Soc. Am. 93 1390-1394.

Dasgupta S, Pande P, Ganguly D, Iqbal Z, Sanyal K and Venkatraman N V et al. 2000 Seismotectonic atlas of India and its environs; Geological Survey of India, Calcutta.

Davis S D and Frohlich C 1991 Single-link cluster analysis, synthetic earthquake catalogs and aftershock identification; Geophys. J. Int. 104 289-306.
Deshikachar S V 1974 A review of the tectonic and geological history of eastern India in terms of "plate tectonics" theory; J. Geol. Soc. India 15 137-149.

Engdahl E, Van der Hilst R and Buland R 1998 Global teleseismic earthquake relocation with improved travel times and procedures for depth determination; Bull. Seismol. Soc. Am. 88 722-743.

Evans P 1964 The tectonic framework of Assam; J. Geol. Soc. India 5 80-96.

Ganesha Raj K and Nijagunappa R 2004 Major lineaments of Karnataka State and their relation to seismicity remote sensing based analysis; J. Geol. Soc. India 63 430-439.

Gangrade B K and Arora S K 2000 Seismicity of the Indian peninsular shield from regional earthquake data; Pure Appl. Geophys. 157 1683-1705.

Gardner J K and Knopoff L 1974 Is the sequence of earthquakes in southern California with aftershocks removed, Poissonian?; Bull. Seismol. Soc. Am. 64(5) 1363-1367.

Gregor N J, Silva W J, Wong I G and Youngs R 2002 Ground motion attenuation relationships for Cascadia subduction zone mega-thrust earthquakes based on a stochastic finite-fault modeling; Bull. Seismol. Soc. Am. 92 1923-1932.

Guha S K and Basu P C 1993 Catalogue of earthquakes $(\mathrm{M} \geq 3.0)$ in peninsular India; Atomic Energy Regulatory Board India, Tech. Document No. TD/CSE-1, pp. 1-70.

Gupta I D 2006 Delineation of probable seismic sources in India and neighborhood by a comprehensive analysis of seismotectonic characteristics of the region; Soil. Dyn. Earthq. Eng. 26 766-790.

Gupta I D 2010 Response spectral attenuation relations for intraslab earthquakes in Indo-Burmese subduction zone; Soil. Dyn. Earthq. Eng. 30 368-377.

Gutenberg B and Richter C F 1956 Magnitude and energy of earthquakes; Annali De Geofisica 9 1-15.

Heaton T H, Tajima T F and Mori A W 1986 Estimating ground motions using recorded accelerograms; Surv. Geophys. 8 25-83.

Iyengar R N and Ghosh S 2004 Microzonation of earthquake hazard in Greater Delhi area; Curr. Sci. 87 1193-1202.

Iyengar R N and Raghu Kanth S T G 2004 Attenuation of strong ground motion in peninsular India; Seismol. Res. Lett. 75(4) 530-540.

Johnston A C 1996 Seismic moment assessment of earthquakes in stable continental regions - Instrumental seismicity; Geophys. J. Int. 124 381-414.

Joshi A, Kapil M and Patel R C 2007 A deterministic approach for preparation of seismic hazard maps in northeast India; Nat. Hazards 43 129-146.

Kaila K L and Sarkar D 1978 Atlas of isoseismal maps of major earthquakes in India; Geophys. Res. Bull. 16 234-267.

Kayal J R 2008 Microearthquake seismology and seismotectonics of south Asia, 1st edn, Springer Verlag and Capital Publishing Company, India, ISBN: 978-1-4020-8179-8.

Kelkar Y N 1968 Earthquakes experienced in Maharashtra during the last 300 years; Daily Kesari Poona, Marathi.

Kolathayar S, Sitharam T G and Vipin K S 2011 Spatial variation of seismicity parameters across India and adjoining areas; Nat. Hazards, doi: 10.1007/s11069-011-9898-1.

Krishnan M S 1953 The structure and tectonic history of India; Geol. Surv. India Memoir 81137.

Kumar P, Yuan X, Ravi Kumar M, Rainer Kind, Xueqing Li and Chadha R K 2007 The rapid drift of Indian tectonic plate; Nature $449894-897$.

Lin P S and Lee C T 2008 Ground-motion attenuation relationships for subduction-zone earthquakes in northeastern Taiwan; Bull. Seismol. Soc. Am. 98 220-240. 
Liu Rui-feng, Chen Yun-tai, Ren Xiao, Xu Zhi-guo, Sun Li, Yang Hui, Liang Jian-hong and Ren Ke-xin 2007 Comparison between different earthquake magnitudes determined by China Seismograph Network; Acta Seismologica Sinica 20(5) 497-506.

Mahajan A K, Thakur V C, Sharma M L and Chauhan M 2009 Probabilistic seismic hazard map of NW Himalaya and its adjoining area, India; Nat. Hazards, doi: 10.1007/s11069-009-9439-3.

Molchan G and Dmitrieva O 1992 Aftershock identification: Methods and new approaches; Geophys. J. Int. 109 501-516.

Molnar P and Tapponnier P 1979 The collision between India and Eurasia; In: Earthquakes and Volcanoes, Proc., from Scientific American, San Francisco: WH Freeman and Company, pp. 62-73.

Nath S K, Vyas M, Pal I and Sengupta P 2005 A hazard scenario in the Sikkim Himalaya from seismotectonics spectral amplification source parameterization and spectral attenuation laws using strong motion seismometry; J. Geophys. Res. 110 B01301, doi: 10.1029/2004/2004J B003199.

Nath S K, Vyas M, Pal I, Singh A K, Mukherjee S and Sengupta P 2006 Spectral attenuation models in the Sikkim Himalaya from the observed and simulated strong motion events in the region; Curr. Sci. 88(2) 295-303.

Nath S K, Raj A, Thingbaijam K K S and Kumar A 2009 Ground motion synthesis and seismic scenario in Guwahati city - a stochastic approach; Seismol. Res. Lett. $80233-242$.

Nath S K and Thingbaijam K K S 2010 Peak ground motion predictions in India: An appraisal for rock sites; J. Seismol., doi: 10.1007/s10950-010-9224-5.

Ni J and Barazangi M 1986 Seismotectonics of the Zagros continental collision zone and a comparison with the Himalayas; J. Geophys. Res. 91 8205-8218.

Oldham T A 1883 Catalogue of Indian earthquakes; Geol. Surv. India Memoir 19 163-215.

Panza G F, Vaccari F and Cazzaro R 1999 Deterministic seismic hazard assessment; In: Vrancea Earthquakes: Tectonics, Hazard and Risk Mitigation (eds) Wenzel F et al. (Netherlands: Kluwer Academic Publishers), pp. 269-286.

Papazachos B C, Karakostas V G, Kiratzi A A, Margaris B N, Papazachos C B and Scordilis E M 2002 Uncertainties in the estimation of earthquake magnitudes in Greece; J. Seismol. 6 557-570.

Parvez I A, Vaccari F and Panza G F 2003 A deterministic seismic hazard map of India and adjacent areas; Geophys. J. Int. 155 489-508.

Purnachandra Rao N 1999 Single station moment tensor inversion for focal mechanisms of Indian intra-plate earthquakes; Curr. Sci. 77 1184-1189.

Raghu Kanth S T G and Iyengar R N 2006 Seismic hazard estimation for Mumbai city; Curr. Sci. 91(11) 1486-1494.

Raghu Kanth S T G and Iyengar R N 2007 Estimation of seismic spectral acceleration in peninsular India; J. Earth Syst. Sci. 116(3) 199-214.

Rao B R and Rao P S 1984 Historical seismicity of peninsular India; Bull. Seismol. Soc. Am. 74(6) 2519-2533.

Rao B V and Murty B V S 1970 Earthquakes and tectonics in peninsular India; J. Indian Geophys. Union 7 1-8.

Rastogi B K 1974 Earthquake mechanisms and plate tectonics in the Himalayan region; Tectonophys. 21 47-56.
Reasenberg P 1985 Second-order moment of central California seismicity 1969-82; J. Geophys. Res. 90 5479-5495.

Reddy P R 2003 Need for high-resolution deep seismic reflection studies in strategic locales of south India; Curr. Sci. 84(8) 973-974.

Savage W U 1972 Microearthquake clustering near Fairview Peak Nevada, and in the Nevada seismic zone; J. Geophys. Res. 77(35) 7049-7056.

Scordilis E M 2006 Empirical global relations converting $\mathrm{M}_{\mathrm{S}}$ and $\mathrm{m}_{\mathrm{b}}$ to moment magnitude; J. Seismol. $10225-236$.

Sharma M L 1998 Attenuation relationship for estimation of peak ground acceleration using data from strong-motion arrays in India; Bull. Seismol. Soc. Am. 88 1063-1069.

Sharma M L and Malik S 2006 Probabilistic seismic hazard analysis and estimation of spectral strong ground motion on bed rock in northeast India; 4th Int. Conf. Earthquake Engineering, Taipei, Taiwan, October 12-13, 2006.

Sharma M L, Douglas J, Bungum H and Kotadia J 2009 Ground-motion prediction equations based on data from the Himalayan and Zagros regions; J. Earthq. Eng. 13 1191-1210.

Shedlock K M 1999 Seismic hazard map of North and Central America and the Caribbean; Annali De Geofisica 42 977-997.

Sitharam T G and Anbazhagan P 2007 Seismic hazard analysis for Bangalore region; J. Nat. Haz. 40 261-278.

Sridevi J 2004 Estimates of plate velocity and crustal deformation in the Indian subcontinent using GPS geodesy; Curr. Sci. 86 1443-1448.

Srivastava H N and Ramachandran K 1985 New catalog of earthquakes for peninsular India during 1839-1900; Mausam 36(3) 351-358.

Stepp J C 1972 Analysis of the completeness of the earthquake sample in the Puget Sound area and its effects on statistical estimates of earthquakes hazard; Proc. Int. Conf. Microzonation for Safer Construct. Res. Appl., Seattle, Washington 64(4) 1189-1207.

Tandon A N and Srivastava H N 1974 Earthquake occurrence in India; In: Earthquake Engineering - Jai Krishna Commemoration Volume, Sarita Prakashan, Meerut, India.

Uhrhammer R A 1986 Characteristic of northern and central California seismicity abstract; Earthquake Notes 121.

Vipin K S, Anbazhagan P and Sitharam T G 2009 Estimation of peak ground acceleration and spectral acceleration for south India with local site effects: Probabilistic approach; Nat. Hazards Earth Syst. Sci. 9 865-878.

Vipin K S and Sitharam T G 2010 Multiple source and attenuation relationships for evaluation of deterministic seismic hazard: Logic tree approach considering local site effects; In: Georisk: Assessment and Management of Risk for Engineered Systems and Geohazards 5(3-4) 173-185, doi: 10.1080/17499518.2010.532015.

Youngs R R, Chiou S J, Silva W J and Humphrey J R 1997 Strong ground motion relationships for subduction earthquakes; Seismol. Res. Lett. 68 58-73.

Zhao J X, Zhang J, Asano A, Ohno Y, Oouchi T, Takahashi T, Ogawa H, Irikura K, Thio H K, Somerville P G, Fukushima Y and Fukushima Y 2006 Attenuation relations of strong ground motion in Japan using site classification based on predominant period; Bull. Seismol. Soc. Am. 96 898-913. 